PF 2019 (LXXIII): 33-48

\author{
MARTA CHOJNACKA-KURAŚ \\ Instytut Języka Polskiego \\ Uniwersytet Warszawski \\ ul. Krakowskie Przedmieście 26/28, 00-927 Warszawa \\ tel. (+48) 225521021 \\ e-mail: marti.ch@wp.pl
}

\title{
KIEDY WALKA STAJE SIĘ PODRÓŻĄ. \\ O PRZEOBRAŻENIACH METAFOR OPISUJĄCYCH DOŚWIADCZENIE CHOROWANIA Z UWZGLĘDNIENIEM TYPU I FAZY CHOROBY
}

SŁOWA KLUCZOWE: dyskurs medyczny, metafora pojęciowa, językoznawstwo kognitywne

KEYWORDS: medical discourse, conceptual metaphor, cognitive linguistics

\author{
WHEN WAR BECOMES A JOURNEY. \\ ON THE TRANSFORMATION OF METAPHORS DESCRIBING \\ THE EXPERIENCE OF ILLNESS WITH REGARD \\ TO THE TYPE AND PHASE OF THE DISEASE
}

\begin{abstract}
The article concerns two conceptual metaphors present in the contemporary medical discourse: DISEASE IS A WAR and DISEASE IS A JOURNEY. Linguistic observations, formulated within the cognitive linguistics framework, are set against the background of medical communication. Based on literature and selected texts representing the Polish medical discourse, the author discusses the structure of both metaphors describing the disease experience. The study seeks to examine the effectiveness of metaphors and possible effects of their use (i.e. metaphorical implications), depending on the disease they relate to, as well as its phase.
\end{abstract}

\section{Wprowadzenie}

Przedmiotem artykułu jest refleksja nad dwiema metaforami konceptualnymi, realizującymi się w tekstach dotyczących choroby i medycyny. Są to: 
najpowszechniejsza $\mathrm{w}$ dyskursie medycznym metafora WROGA albo PRZECIWNIKA ${ }^{1}$, tworząca ogólny schemat metaforyczny WALKI Z CHOROBĄ, oraz rzadziej reprezentowana metafora PODRÓŻY, ukazująca doświadczenie choroby jako PODRÓŻOWANIE, BYCIE W DRODZE. Interesują mnie przede wszystkim struktury obu tych metafor oraz możliwe konsekwencje ich stosowania w dyskursie, w zależności od tego, do jakiego typu choroby lub do jakiej fazy chorowania się odnoszą. Jeśli chodzi o strukturę metafor, mam na myśli zarówno ich elementy zakodowane w wyrażeniach językowych, jak i treści potencjalne, metaforyczne implikacje, które mogą się pojawić w świadomości uczestników dyskursu na zasadzie wnioskowania.

Sformułowanie o przeobrażeniach metafor, wynikające ze wstępnych obserwacji dyskursu o medycynie oraz przeglądu zagranicznych badań, traktuję jako tezę, którą chciałabym dalej rozwijać. Myślenie o elastyczności w doborze metafor może być także postulatem dotyczącym sposobów porozumiewania się przedstawicieli opieki medycznej z pacjentami i szerzej - mówienia o chorobach i chorych w polskim dyskursie publicznym. Wypowiedź umieszczam w kontekście komunikacji medycznej i roli języka (w tym szczególnej roli metafory) $\mathrm{w}$ procesie porozumiewania się z osobami chorymi. Komunikację medyczną rozumiem szeroko i nawiązuję tu do rozważań Jana Doroszewskiego (2007, s. 43), dla którego komunikacja medyczna w wąskim sensie oznacza relację między personelem medycznym i pacjentem, zaś w szerokim ujęciu jest to „porozumienie między różnymi - pojedynczymi lub zbiorowymi - podmiotami, które dotyczy spraw związanych z medycyną"2.

Jeśli chodzi o rozumienie dyskursu medycznego, to chciałabym objąć myślą różnego typu teksty powiązane tematycznie: dotyczące zdrowia, choroby, medycyny, także funkcjonowania opieki medycznej. Interesują mnie przede wszystkim teksty „niespecjalistyczne”, dostępne dla szerokiego grona odbiorców, odzwierciedlające sposoby postrzegania zdrowia, choroby i medycyny przez nadawców należących do danej społeczności językowo-kulturowej. Z pola uwagi wyłączam zatem artykuły i podręczniki medyczne mające z założenia przedstawiać obiektywny, naukowy, „mierzalny” stan rzeczy. Przykłady, które przywołuję w artykule, pochodzą z dwóch źródeł należących do tak rozumianego dyskursu: z książki

\footnotetext{
1 Zgodnie z konwencją przyjętą w literaturze lingwistycznej „etykiety” nazywające metafory oraz domeny pojęciowe zapisuję wersalikami.

2 Jeśli przyjmiemy, że medycyna to "nauka o zdrowiu i chorobach człowieka oraz o sposobach ich leczenia; także: sztuka leczenia chorych i zapobiegania chorobom" (zgodnie z definicją w USJP), to można włączyć tu wszelkie akty komunikacji, których tematem są: zdrowie, chorowanie, sposoby leczenia chorób i zapobiegania im, także te akty komunikacyjne zachodzące bez udziału środowiska medycznego (np. między chorymi, rodzinami chorych, między chorymi a społeczeństwem).
} 
Być pacjentem, być lekarzem. Rozmowy o psychologii relacji (rozmowa Ireny Stanisławskiej z psychologiem Wojciechem Eichelbergerem, 2013) oraz z książki Żyć aż do końca. Instrukcja obsługi choroby (rozmowa Katarzyny Jabłońskiej z ks. Janem Kaczkowskim, 2017).

Postać ks. Kaczkowskiego i publikowane z nim rozmowy, szczególnie ta ostatnia, zasługują w moim odczuciu na słowo komentarza. Książka Żyć aż do końca została pomyślana jako przewodnik po chorowaniu i umieraniu, a więc jako tekst o zastosowaniu praktycznym, dający czytelnikom konkretne wskazówki, instrukcje działania w obliczu choroby (zarówno własnej, jak i kogoś bliskiego). Mają one postać siedmiu niezbędników: dla lekarza, dla chorego, dla jego bliskich, dla pacjentów i pracowników hospicjum, dla osób walczących z bólem oraz dla kapelana szpitalnego i hospicyjnego. Działalność ks. Kaczkowskiego na rzecz ludzi chorych jest powszechnie znana ${ }^{3}$. On sam należy do grona osób, które publicznie przyznały, że chorują na raka, i ujawniły różnorodne wymiary swojego doświadczenia - w sposób szczery, językiem przystępnym, neutralnym, wolnym od zbędnych wartościowań. $\mathrm{W}$ jednym $\mathrm{z}$ rozdziałów książki przyznał:

(...) swoje chorowanie uczyniłem sprawą publiczną. To grozi pornografią chorowania czy umierania, oczywiście chciałbym tego uniknąć. Jeśli jednak okazałoby się, że te moje działania chociaż jednemu człowiekowi pomogły pokonać lęk czy zmobilizowały go do badania się i dzięki temu wykryto u niego nowotwór w bardzo wczesnym stadium rozwoju, to warto było podjąć takie ryzyko. Ludzie, badajcie się! (Jabłońska, Kaczkowski 2017, s. 69).

Tego typu publikacje kształtują sposób myślenia odbiorców (czytelników) o chorobie nowotworowej, opiece paliatywnej, lekach opioidowych, wreszcie o fenomenie hospicjum i końcowym etapie życia. Kiedy o chorobie i wszystkim, co się z nią wiąże, tak otwarcie mówią osoby publiczne, to ta choroba stopniowo przestaje być czymś nieznanym (postrzeganym emocjonalnie, w sposób uproszczony), czymś wstydliwym, stygmatyzującym; przestaje być tematem tabu. Poznanie doświadczeń innych osób - tym bardziej osób znanych - pozwala „Zwykłym” ludziom (tak chorym, jak i zdrowym) w jakimś stopniu odczarować własne wyobrażenia o chorobie, zrozumieć i oswoić to zjawisko, zapanować nad lękiem przed rakiem i jego mitem - tym, o którym czterdzieści lat temu pisała Susan Sontag $(1978,1988)^{4}$.

3 Ks. Jan Kaczkowski (1977-2016) był współtwórcą i prezesem Puckiego Hospicjum pw. św. Ojca Pio. Był także kapelanem domu pomocy społecznej i szpitala w Pucku. Organizował Areopagi Etyczne, czyli warsztaty dla studentów medycyny, podczas których przyszli lekarze uczyli się, jak dobrze komunikować się z pacjentami.

$4 \quad \mathrm{Na}$ potrzeby artykułu korzystam $\mathrm{z}$ ostatniego polskiego wydania esejów Susan Sontag w tłumaczeniu Jarosława Andersa (Sontag 2016). 
Choć refleksje S. Sontag w jakimś stopniu nadal oddają stan świadomości polskiego społeczeństwa na temat choroby nowotworowej, to trzeba przyznać, że w ostatnich latach sporo się „wokół raka” zmieniło. W jednym z wywiadów na temat idei współodczuwających społeczności lokalnych (ang. compassionatecommunity) w Polsce ks. prof. Piotr Krakowiak, krajowy duszpasterz hospicjów, przyznał wręcz, że pacjenci nowotworowi są „dopieszczeni” przez media, a przez to i oni, i ich opiekunowie „mają niejako szczęście”. W gorszej pod tym względem sytuacji są chorzy na inne choroby, równie groźne, długotrwałe i skomplikowane w przebiegu, ale nieomawiane w takim stopniu w dyskursie publicznym jak choroby nowotworowe ${ }^{5}$. Te inne choroby oraz sposoby opowiadania o nich również zasługują na uwagę badaczy dyskursu medycznego.

\section{Założenia metodologiczne}

Jako podstawę teoretyczną przyjmuję założenia językoznawstwa kognitywnego, czyli tego nurtu współczesnej lingwistyki, który przedmiotem rozważań czyni relację między umysłem, percepcją rzeczywistości a językiem, przy czym język traktuje jako jedną ze zdolności poznawczych człowieka. Takie podejście, reprezentowane m.in. przez Ronalda Langackera, George’a Lakoffa czy Gillesa Fauconniera, akcentuje związek działalności językowej człowieka z całością jego psychofizycznego doświadczenia: bycia w danej społeczności, w kulturze i bycia jednostką biologiczną ${ }^{6}$. Zgodnie z założeniami kognitywizmu sposób mówienia wiąże się ze sposobem interpretowania rzeczywistości, a zmiana sposobu myślenia o czymś - na przykład o doświadczeniu choroby nieuleczalnej - wymaga zmiany sposobu mówienia o tym.

Choć uważam, że teoria metafory pojęciowej George’a Lakoffa i Marka Johnsona $(1980,2010)$, ze względu na swoją statyczność i jednostronność relacji między domenami, nie jest wystarczająca do opisu dynamicznych modeli pojęciowych choroby realizujących się $\mathrm{w}$ dyskursie, to na tym etapie myślenia będę się nią posługiwać, ale w połączeniu z koncepcją ram interpretacyjnych Charlesa Fillmore’a $(1982,1985)^{7}$. Uzupełnienie znanych opisów metafor SPÓR TO WOJNA oraz ŻYCIE TO PODRÓŻ (zawierających interesujące mnie domeny WALKI

\footnotetext{
$5 \quad$ Rozmowa Magdy Małkowskiej z ks. Piotrem Krakowiakiem opublikowana jest w kwartalniku hospicyjnym Hospicjum to te $\dot{z}$ zycie (2017).

6 Relację między językiem a doświadczeniem widać szczególnie w takich koncepcjach, jak: gramatyka kognitywna R. Langackera (2009), schematy wyobrażeniowe G. Lakoffa (1987) czy metafora pojęciowa G. Lakoffa i M. Johnsona (1980).

7 Odwołuję się w tym miejscu do metodologii opisu metafor synestezyjnych stosowanej w projekcie SYNAMET (por. Zawisławska 2016).
} 
i PODRÓŻY) o ujęcie ramowe pozwoli wniknąć w strukturę modeli pojęciowych CHOROBY jako WALKI i jako PODRÓŻY i pokazać elementy (a nawet całe scenariusze), które tworzą analogie między zestawianymi domenami.

\section{Choroba, medycyna i metafora w literaturze przedmiotu - zarys}

Refleksję na temat metafor choroby chciałabym osadzić w kontekście publikacji, które dla podjętego przeze mnie zagadnienia wydają się istotne.

Połączenie pojęć choroba i metafora prowadzi prosto do wspomnianych już dwóch esejów S. Sontag $(1978,1988)$, które są punktem wyjścia dla każdego, kto porusza zagadnienie metafor choroby czy metaforyki w medycynie. Dla mnie szczególnie ważny jest sformułowany przez autorkę postulat, że choroba powinna być odarta z metaforycznych znaczeń, aby można było ją postrzegać w kategoriach biologicznych, naturalnych, a nie społecznych i moralnych ${ }^{8}$. Obserwacja dyskursu o zdrowiu, chorobie i medycynie zdaje się potwierdzać, że postulat ten nie jest realny; człowiek potrzebuje metafory, aby zrozumieć fenomen choroby, nadać temu doświadczeniu jakieś znane ramy pojęciowe. Sama Sontag rozpoczęła swój esej Choroba jako metafora metaforą: „Choroba jest nocną stroną życia, naszym bardziej uciążliwym obywatelstwem” (Sontag 2016, s. 5)9. Później przyznała, że był to „żartobliwy egzorcyzm uwodzicielskiej siły metaforycznego myślenia”, że nie można myśleć bez metafor, ale należy posługiwać się nimi świadomie, a niektóre z nich - szczególnie metaforykę wojenną - świadomie odrzucić (Sontag 2016, s. 87-88).

Inspirujące dla moich rozważań konkluzje zawiera artykuł dwóch amerykańskich onkologów, Gary’ego Reisfielda i George’a Wilsona (2004, s. 4026-4027) ${ }^{10}$, którzy piszą wprost o konieczności wspólnego wypracowywania (negocjowania) przez lekarza i pacjenta metafory, w ramach której osadzone ma być indywidualne doświadczenie choroby oraz postępowanie medyczne:

8 W eseju AIDS i jego metafory S. Sontag pisze tak o chorobie nowotworowej, której poświęciła swój wcześniejszy esej: „Miałam nadzieję, że przekonam przerażonych, by szukali pomocy lekarza lub szukali lekarzy bardziej kompetentnych, takich, którzy zapewnią im odpowiednią opiekę. By uważali raka po prostu za chorobę - bardzo poważną, lecz tylko chorobę. Nie za przekleństwo, nie karę, nie powód do wstydu. Za coś, co nie ma ukrytego »znaczenia «. I niekoniecznie za wyrok śmierci (jedna z mistyfikacji to twierdzenie, że rak = śmierć)" (Sontag 2016, s. 96; podkr. M. Ch.-K.).

9 Dziękuję dr Monice Ładoń za ten głos w dyskusji podczas konferencji o dyskursie medycznym we Wrocławiu w 2017 r.

10 Korzystam z wersji elektronicznej artykułu zamieszczonej na stronie internetowej Journal of Clinical Oncology: http://ascopubs.org/doi/10.1200/JCO.2004.03.136. 
Ask patients if your proposed metaphors are appropriate. Be cognizant of the fact that some patients may find the use of certain metaphors inappropriate (e.g. war) or dehumanizing (e.g. the body as a broken machine). Listen for patients' metaphoric expressions. Elicit them if necessary. By paying attention to patients' metaphoric speech, physicians may gain some insight into the cognitive and affective underpinnings of their illness experience, and this may help make sense of their questions, their demands, their emotional responses, and their treatment decisions. (...) Respect patients' metaphors but, if appropriate, try introducing alternate or parallel metaphoric concepts that may be more enabling ${ }^{11}$.

Za cenny uważam artykuł Jana Domaradzkiego (2015) o metaforach w medycynie i o ich roli w komunikacji między lekarzami i pacjentami. Jest to przegląd opracowań zagranicznych, zwłaszcza amerykańskich i brytyjskich, pokazujący, jak bardzo zaawansowane są na świecie badania nad metaforyką choroby i jak wiele uwagi poświęca się w nich strukturze metafor (zwłaszcza WALKI Z CHOROBĄ) i ich wpływowi na funkcjonowanie i postrzeganie choroby i osób chorych w społeczeństwie.

Ze względu na tematykę, a częściowo także przyjętą metodologię, kluczową dla mnie pozycją jest najnowsza monografia autorstwa Eleny Semino i jej zespołu pt. Metaphor, Cancer and the End of Life. A Corpus-based Study (2018). Książka przedstawia założenia, metodologię oraz wyniki projektu, którego celem było opisanie metafor, za pomocą których współcześni Brytyjczycy mówią o doświadczeniu choroby nowotworowej i opiece medycznej w dwóch ostatnich latach życia chorego. W badaniach uwzględniono trzy perspektywy: chorych, opiekujących się nimi osób oraz lekarzy specjalistów. Do opisu metafor zastosowano teorię metafory pojęciowej Lakoffa i Johnsona. Podstawową tezą autorów, którą udowadniają w kolejnych rozdziałach książki, jest to, że efekty metafor są ściśle uzależnione od kontekstu i danego użycia: różni ludzie mogą odwoływać się do tych samych, ogólnych modeli metaforycznych na różne sposoby i na różnych etapach opisywanego doświadczenia.

Z prac polonistycznych, w których pojawiają się elementy opisu metafor choroby w języku ogólnym, wymienić warto m.in. artykuł Stanisławy Niebrzegowskiej-Bartmińskiej (2006) o konceptualizacji choroby w języku potocznym i w zamówieniach ludowych oraz językowo-kulturowe studium choroby autorstwa Marzeny Marczewskiej (2012). Wymienione w nich najczęstsze domeny

11 Zapytaj pacjenta, czy zaproponowane przez ciebie metafory są odpowiednie. Miej świadomość, że niektórzy pacjenci mogą uznać użycie danej metafory za niewłaściwe (np. metafora wojny) lub odczłowieczające (np. metafora ciała jako zepsutej maszyny). Słuchaj, jakich wyrażeń metaforycznych używają pacjenci. Wywołaj je w razie potrzeby. Poprzez obserwację metaforycznych wypowiedzi pacjentów lekarz może uzyskać wgląd w poznawcze i emocjonalne podstawy ich doświadczenia choroby, a przez to zrozumieć sens zadawanych pytań, formułowanych żądań, reakcji emocjonalnych i decyzji dotyczących leczenia. (...) Szanuj metafory, którymi posługują się pacjenci, ale w razie potrzeby próbuj przedstawiać alternatywne modele metaforyczne, które mogą być bardziej pomocne (tłum. - M. Ch.-K.). 
źródłowe metafor choroby w polszczyźnie to: RZECZ, CIĘŻAR, POJEMNIK, DÓŁ (PRZEPAŚĆ), CZŁOWIEK $\rightarrow$ WRÓG/NAJEŹDŹCA/PRZECIWNIK; ciało przedstawiane jest najczęściej jako POJEMNIK NA CHOROBĘ lub POLE BITWY. Zawarte w tych dwóch pracach uwagi na temat metafor choroby są dość ogólne. Celem autorek nie była ani analiza współczesnego dyskursu, ani refleksja o strukturach i oddziaływaniu metafor na uczestników dyskursu.

Tematyka choroby jest podejmowana przez przedstawicieli różnych dyscyplin humanistyki, wśród których zdają się dominować: antropologia, kulturoznawstwo, literaturoznawstwo i socjologia. W polskich badaniach lingwistycznych nad metaforami w medycynie i w dyskursie, tym bardziej w kontekście komunikacyjnym, jest sporo do zrobienia. Prezentowany artykuł jest wstępem do podjętych przeze mnie badań nad zmianami modeli pojęciowych choroby i chorowania we współczesnym polskim dyskursie medycznym.

\section{Metafora militarna $w$ dyskursie medycznym}

Metafora WALKI albo WOJNY jest skonwencjonalizowana i mocno zakorzeniona w kulturze zachodniej. Jak pisze m.in. J. Domaradzki (2015), domena WALKI przywoływana jest w opisach różnorodnych dziedzin, np. sportu, ekonomii, religii czy polityki. Obrazuje negatywne, szkodliwe z czyjejś perspektywy zjawiska zachodzące w przestrzeni publicznej, z którymi społeczeństwo (najczęściej reprezentowane przez określone instytucje państwowe) podejmuje walkę, aby je wyeliminować.

Dyskurs medyczny również jest „przesiąknięty” metaforyką militarną: jest ona obecna w języku naukowym, posługują się nią sami pacjenci, a także autorzy przekazów medialnych ${ }^{12}$. Myślenie o chorobie jako PRZECIWNIKU jest „użyteczne” z punktu widzenia medycyny: wyznacza sposób postrzegania abstrakcyjnych pojęć (zdrowia i choroby), pozwala ustrukturyzować całościowe wyobrażenie choroby jako wroga i zaprojektować działania skuteczne i pożądane z perspektywy nauki, która ma chronić społeczeństwo przed zagrożeniem (bólem, patologicznym stanem ciała, śmiercią). To „Zapotrzebowanie” medycyny na metaforykę wojenną oraz wielopoziomowe analogie między wojną a zmaganiami pokoleń lekarzy z rakiem znakomicie opisał amerykański onkolog Siddhartha Mukherjee w książce Cesarz wszech chorób. Biografia raka (2013).

12 Metafora wojenna jest obecna w publicystyce, reklamie, posługują się nią fundacje działające na rzecz pacjentów, ubezpieczyciele itd. Hasła typu: zwalcz szybko objawy przeziębienia i grypy, nie daj się chorobie, Apap skutecznie zwalcza ból, pokonaj raka, walka z rakiem, wygrać z choroba dla większości użytkowników polszczyzny brzmią naturalnie, stają się oczywistym (a często zleksykalizowanym, dosłownym) sposobem mówienia o chorobie. Wydaje się, że metaforyczność tego typu wyrażeń ożywa dopiero przy bardziej okazjonalnych realizacjach, kiedy w dyskursie pojawiają się nieoczywiste elementy ramy WALKI lub kiedy przekaz jest multimodalny (np. językowo-wizualny), a przez to wzbogacony o dodatkowe treści. 
W wielu pracach lingwistycznych opisujących konceptualizację choroby (np. Stec 2007; Malinowska 2013) i metafory w medycynie mówi się o chorobie bardzo ogólnie, tak jakby była zjawiskiem jednorodnym. Tymczasem w zależności od typu choroby paralele między domenami zestawianymi w metaforze, np. WALKI i CHOROBY, będą mniej lub bardziej rozbudowane. Scenariusz walki z chorobą ostrą (typu: angina) będzie prostszy, zaś z chorobą nowotworową, która łączy cechy choroby śmiertelnej i przewlekłej, bardziej rozbudowany. Są jednak publikacje, w których wyróżnia się i opisuje konkretne jednostki chorobowe. Na przykład w opracowaniu sposobów przedstawiania niezakaźnych chorób przewlekłych w dyskursach potocznym i prasowym autorzy skupili się na reumatyzmie i łuszczycy (Libura, Bechler 2015). Takie postępowanie jest zasadne. W analizie sposobów obrazowania choroby, także w opisie metafor, należy przyjąć choćby podstawowe rozróżnienie: na choroby ostre i przewlekłe, sprecyzować domenę docelową (o jaką chorobę chodzi) i zastanowić się, czy dana metafora jest strukturalnie adekwatna do opisywanej rzeczywistości (jak przedstawia doświadczenie tej konkretnej choroby, jak ukazuje chorego, jakie może mieć implikacje itd.).

Metafora WALKI Z CHOROBĄ wydaje się skuteczna przy chorobach krótkotrwałych, o jasno określonych przyczynach, takich jak: zapalenie oskrzeli, infekcje wirusowe czy bakteryjne. Rozwój medycyny, określone procedury, schematy działania, dostępność leków sprawiają, że od samego początku pacjent jest na pozycji wygranej: wystarczy zadziałać w odpowiedni sposób i choroba zostanie pokonana. Przypuszczam, że z perspektywy pacjenta przywołanie domeny WALKI jest skuteczne i pożyteczne także na kilku etapach choroby nowotworowej, zwłaszcza na początku, przy wczesnym wykryciu, kiedy są dobre rokowania, a pacjent ma duże szanse na wyzdrowienie (w tym momencie ważne są: mobilizacja, postawa aktywna, wiara w skuteczność leczenia i nadzieja). W przebiegu każdej choroby długotrwałej zdarzają się momenty, kiedy metaforyka militarna może na nowo zmobilizować pacjenta do działania. Jest to kwestia bardzo indywidualna, ważne jest wyczucie lekarza, jak pacjent „czuje się w tej metaforze”, jak na nią reaguje. Przykładem dość oryginalnej, ale zaakceptowanej przez uczestników komunikacji, realizacji metafory WALKI Z CHOROBĄ jest poniższy fragment:

W wielu krajach leczenie w wypadku glejaka czwartego stopnia (...) jest kontynuowane bardziej wytrwale niż w Polsce. Medyków nie zniechęca fakt, że mamy do czynienia z groźnym przeciwnikiem, który najczęściej pokonuje chorego. (...) Znajoma pielęgniarka (...) przeżyła niedawno załamanie. Prowadzący terapię lekarz tłumaczył jej spokojnie, że to nie ostatnia strzała z naszego kołczanu. (...) Podobnie i u mnie, szwajcarski profesor zapewnia, że mamy odłożoną amunicję na najczarniejsze scenariusze. Wierzę mu i to mnie uspokaja, co nie oznacza, że profesor nie sygnalizuje delikatnie, że tych naboi jest coraz mniej (Jabłońska, Kaczkowski 2017, s. 76-77). 
W przypadku chorób przewlekłych, z którymi pacjent żyje aż do śmierci, których nie może pokonać, metafora WALKI wydaje się z gruntu nietrafiona. Ta walka nie może zakończyć się zwycięstwem pacjenta, od samego początku jest on na przegranej pozycji. Podobnie dzieje się w zaawansowanym stadium raka, w fazie terminalnej, kiedy leczenie przyczynowe zostało wyczerpane, chory umiera i nie ma szansy na wygraną. W ramach tej metafory pacjent umiera jako przegrany, pokonany przez ciężką chorobę, słaby. Jak pokazują badania E. Semino, w odczuciu wielu pacjentów w Wielkiej Brytanii taka konceptualizacja jest krzywdząca, potrzebne są inne ramy myślenia o doświadczeniu choroby nowotworowej ${ }^{13}$.

\section{Struktura metafory WALKI Z CHOROBĄ i zarzuty wobec niej}

Uwzględniwszy opisy tej metafory w literaturze przedmiotu oraz jej realizacje $\mathrm{w}$ analizowanych przeze mnie tekstach, proponuję następujący schemat relacji między elementami ramy WALKI i ramy CHOROBY (tu konkretnie NOWOTWORU):

\begin{tabular}{|l|}
\hline Elementy ramy WALKI \\
Walczący (żołnierz) \\
Dowódca \\
Wróg, agresor, przeciwnik \\
Państwo zaatakowane, pole walki \\
System obronny państwa \\
Broń \\
Taktyka, metody walki, kontratak \\
Sojusznicy \\
Akcje przeciwnika: ataki, napaści \\
Zwycięstwo \\
Przegrana \\
Zawieszenie broni? \\
Przemoc, siła, agresja \\
Stan gotowości bojowej
\end{tabular}

\begin{tabular}{|l|}
\hline Elementy ramy CHOROBY \\
Pacjent, chory człowiek \\
Lekarz \\
Choroba (wirusy, komórki rakowe) \\
Ciało (organizm) chorego \\
Układ immunologiczny pacjenta \\
Medycyna: leki, chemia, operacje itd. \\
Plan leczenia, procedury medyczne \\
Personel medyczny, rodzina \\
Początek choroby, wznowy, przerzuty \\
Pokonanie choroby (wyzdrowienie) \\
Śmierć \\
Pogodzenie się zchorobą? \\
Wyniszczające, agresywne leczenie \\
Chory zmobilizowany, stale aktywny \\
\hline
\end{tabular}

Rys. 1. Relacje między elementami ram WALKI i CHOROBY

13 Doniesienie o badaniach E. Semino pochodzi ze strony internetowej Lancaster University: http://www.lancaster.ac.uk/news/articles/2014/battle-metaphors-for-cancer-can-be-harmful/. 
W literaturze zagranicznej dużo uwagi poświęcono krytyce metafory WALKI Z CHOROBA, stosowanej w brytyjskim i amerykańskim dyskursie medycznym. Domaradzki (2015, s. 35) przywołał w swoim artykule najważniejsze zarzuty wobec takiego postrzegania choroby. Referuję je za autorem poniżej:

- metaforyka militarna wydobywa wyłącznie złe aspekty choroby, ujmuje ją jako zewnętrznego agresora; nie pokazuje, że choroba może człowieka wzbogacić, być doświadczeniem przewartościowującym życie;

- akcentuje agresywne, inwazyjne metody leczenia, pomija terapie alternatywne;

- realizuje biomedyczne ujęcie choroby, pomija czynniki psychospołeczne (nie wyraża tym samym holistycznego podejścia do pacjenta);

- stwarza fałszywe przekonanie, że zwycięstwo (czyli wyzdrowienie, pokonanie choroby) wymaga jedynie silnej woli i chęci wygranej, co może dawać chorym błędne poczucie kontroli nad chorobą;

- w przypadku niepowodzenia pacjenci, którzy „ulegli” i „przegrali” z chorobą, mogą odczuwać wstyd i mieć poczucie, że niewystarczająco się starali; choroba może być traktowana jako osobista porażka; pacjenci, którzy odmawiają uczestnictwa w terapii (zwłaszcza agresywnej, inwazyjnej), mogą być postrzegani jako „dezerterzy z pola walki”, co z kolei wiąże się z piętnem "tchórza”;

- metaforyka wojny stawia w centrum zainteresowań lekarza chorobę, a nie pacjenta, przez co dehumanizuje relację terapeutyczną i uprzedmiotawia chorego, którego ciało staje się polem działania lekarza;

- język wojny, napaści, ataku, terroru stwarza poczucie ciągłego zagrożenia.

Niektóre z tych zarzutów użytkownikom współczesnej polszczyzny mogą się wydawać nieco nadinterpretowane. Być może jest to kwestia różnic językowo-kulturowych. Jednak w tekstach, które wybrałam do analizy, znalazłam fragmenty pokazujące negatywne konsekwencje stosowania w dyskursie medycznym modelu pojęciowego opartego na metaforze WALKI Z CHOROBĄ. Przejawiają się one m.in. w postawach niektórych lekarzy wobec pacjentów terminalnych, „nierokujących", a także w sposobie funkcjonowania placówek opieki zdrowotnej. Oto przykładowe konteksty zaczerpnięte z książki Być lekarzem, być pacjentem (2013):

Niestety dla większości lekarzy choroba jest przeciwnikiem, a pacjent tylko areną, na której rozgrywa się walka. Dlatego gdy lekarz „przegrywa z chorobą”, to z reguły opuszcza pacjenta. Tak jak zawstydzony przegraną sportowiec - schodzi z boiska. Mecz się skończył i lepiej o porażce jak najprędzej zapomnieć. Dopóki pacjent walczy (...), jest otoczony pielęgniarkami, lekarzami, słyszy doping rodziny i znajomych. Gdy (...) akceptuje przegraną i godzi się ze śmiercią, nagle zostaje sam. (...) To najgorszy moment, aby zmęczonego wojownika o przeżycie, człowieka, który przegrał z chorobą, porzucić (s. 110-111). 
Ale gdy szpital nieustannie działa na zasadzie instytucji wojskowej, to trudno mu będzie zreformować relacje lekarzy i pacjentów. Bo wtedy pacjent nie jest osobą, tylko chorobą, z którą trzeba walczyć. Więc lekarze walczą z chorobą, a nie zajmują się pacjentem. Pacjent ich nie interesuje. W istocie przeszkadza (s. 83).

W szpitalu pacjenci umierają najczęściej jak ciężko znokautowani, nieprzytomni bokserzy na ringu (...), bo nikt nie odważył się w porę przerwać nierównej walki (s. 114).

Może to też być komunikat nie wprost, że pacjent nie chce dłużej walczyć o życie przy zastosowaniu uporczywej terapii, że chce sensownie i przytomnie przeżyć resztę swoich dni. Taką decyzję pacjenta trzeba uszanować i nie obrażać się na niego, nie traktować go jak zawiedziony trener zawodnika, który nie chce walczyć z przeciwnikiem, z którym nie ma szans (s. 115).

\section{Metafora PODRÓŻY w dyskursie medycznym}

Dla badaczy brytyjskiego i amerykańskiego dyskursu medycznego alternatywą wobec metaforyki militarnej jest m.in. metafora PODRÓŻY. Domaradzki (2015, s. 39) przywołuje stanowisko Richarda Pensona i jego współpracowników (2004), którzy proponują stosowanie tej metafory ze względu na jej korzystne właściwości. Najważniejsze z nich wymieniam poniżej:

- wyobrażenie PODRÓŻY ujmuje chorobę jako wyzwanie, podobnie jak domena WALKI (czyli nie wyklucza mobilizacji pacjenta, jego aktywnej postawy), ale w przeciwieństwie do niej daje pacjentowi wybór, jaką drogą chce iść (a także: jak szybko chce iść, czy chce odpocząć - to są potencjalne implikacje, jakie z tej metafory mogą wynikać);

- przedstawia chorobę jako okazję do osobistego rozwoju człowieka (potoczna wiedza podpowiada, że podróże kształcą, człowiek poznaje siebie, swoich bliskich, swoje możliwości; jest to czas na autorefleksję); myślenie o chorobie jako PODRÓŻY pozwala przygotować się na śmierć; może być dla chorego źródłem nadziei;

- domena PODRÓŻY nie zakłada dychotomicznego podziału na zwycięstwo i porażkę, przez co nie obarcza pacjenta poczuciem winy za pogorszenie stanu zdrowia, wznowy w chorobie nowotworowej czy wejście w fazę terminalną choroby;

- wyobrażenie PODRÓŻY nie wywołuje negatywnych skojarzeń i emocji, jakie towarzyszą zwykle wyobrażeniom wojny, walki, agresji przeciwnika.

Metafora CHOROBA TO PODRÓŻ jest związana z metaforą ŻYCIE TO PODRÓŻ. Przypuszczam wręcz, że może się z niej wywodzić. W tekstach realizujących tę metaforę chorowanie jest ujmowane jako część życia, życie z chorobą 
jest codziennym byciem tu i teraz. Przykładem realizacji tego modelu pojęciowego chorowania są wypowiedzi ks. Jana Kaczkowskiego, formułowane w kontekście opieki paliatywno-hospicyjnej, w których splatają się pojęcia: CHOROBA, ŚMIERĆ i ŻYCIE. W słowach ks. Kaczkowskiego pojawiają się odniesienia do domeny PODRÓŻY. Na potrzeby opisu doświadczenia nieuleczalnej choroby jako części życia wydobyte zostają takie komponenty pojęciowe, jak: zmierzanie do celu, którym jest koniec życia (śmierć), uważne przeżywanie kolejnych dni (jak przemierzanie kolejnych odcinków drogi), cieszenie się każdą chwilą (jak widokami w podróży), pogodzenie się z losem, które nie oznacza bierności, tylko aktywną, świadomą, spokojną postawę, bez poczucia przymusu (chory nie walczy z przeciwnikiem, tylko idzie przed siebie), skupienie się na teraźniejszości, na najdrobniejszych aspektach życia. Oto kilka fragmentów z książki Żyć aż do końca (2017):

Pozwolić się choremu poprowadzić za rękę przez jego chorobę. (...) Chory, który dłużej choruje, będzie miał doświadczenie i będzie potrafił być dla nas przewodnikiem po własnej chorobie (s. 128).

Przecież życie dzieje się tu i teraz, a nie w nieokreślonej przyszłości, kiedy chory wyzdrowieje. Tym bardziej że może nie wyzdrowieć (s. 141).

Chorowanie - tak jak umieranie - jest włączone w ten jednorazowy i niepowtarzalny projekt, jakim jest życie każdego z nas. (...) Ja swojej choroby nie afirmuję, staram się jednak żyć w niej najpełniej, jak potrafię. Bo chorowanie to przecież wciąż życie, które można wypełnić sensem (s. 56).

Myślę, że ks. Kaczkowski posługuje się tą konceptualizacją świadomie: jest ona ważna w medycynie paliatywnej, w opiece hospicyjnej, która stawia sobie inne zadania niż medycyna nastawiona na wyleczenie chorego. $\mathrm{W}$ ramach opieki paliatywnej pacjent nie walczy $\mathrm{z}$ chorobą i w związku z tym nie przegrywa $\mathrm{z}$ nią; zamiast tego żyje spokojnie do samego końca. W wypowiedziach ks. Kaczkowskiego jest mowa o walce. Wyrażenia walczyć o coś czy nie poddawać się wydają się niezastępowalne w kontekście aktywnej opieki nad chorym. Są jednak używane w innym odniesieniu i przez to nie uaktywniają pełnego scenariusza WALKI Z CHOROBĄ wraz z wszystkimi możliwymi implikacjami. Oto przykład:

Naszym zadaniem w hospicjum jest ustabilizowanie stanu chorego oraz uświadomienie jemu oraz jego bliskim, że walka wcale nie została zakończona. Trwa nadal - o komfort życia naszego pacjenta w chorobie, o każdy dzień, godzinę, minutę jego życia. To jest w pełni profesjonalne leczenie, tyle że weszło w inny etap (s. 153).

W wypowiedziach ks. Kaczkowskiego przeciwnikiem w walce nie jest choroba jako taka, tylko konkretne dolegliwości chorego, ból, duszności, brak apetytu; to nie pacjent się nie poddaje, tylko personel sprawujący nad nim opiekę (lekarze, 
pielęgniarki, wolontariusze, również rodzina); inny jest także cel działań podejmowanych przez opiekunów: nie jest to walka o zdrowie, ratowanie pacjenta za wszelką cenę, tylko walka o każdy dzień, o pełne i godne przeżycie ostatnich chwil życia.

\section{Struktura i właściwości metafory CHOROBA TO PODRÓŻ}

O strukturze tej metafory nie ma zbyt wielu wzmianek w literaturze. Wziąwszy pod uwagę opisy innych metafor, w których PODRÓŻ jest domeną źródłową, oraz realizacje takiej konceptualizacji choroby w badanych tekstach, proponuję następujący schemat relacji między elementami ramy PODRÓŻY i ramy CHOROBY (NOWOTWOROWEJ):

\begin{tabular}{|c|c|}
\hline Elementy ramy PODRÓŻY & Elementy ramy CHOROBY \\
\hline Podróżnik, wędrowiec & Pacjent, chory człowiek \\
\hline Trasa podróży & Przebieg (czas) choroby i leczenia \\
\hline Cel podróży & Kolejny rok, dzień, wyzdrowienie \\
\hline $\begin{array}{l}\text { Różne punkty (miejsca) } \\
\text { i zdarzenia na trasie }\end{array}$ & $\begin{array}{l}\text { Momenty w chorowaniu, poprawy, } \\
\text { pogorszenia, wznowy, pobyty } \\
\text { w szpitalu, konsultacje }\end{array}$ \\
\hline Różne drogi na mapie & $\begin{array}{l}\text { Różne możliwości leczenia, opieki } \\
\text { nad chorym }\end{array}$ \\
\hline Towarzysze podróży & Bliscy, personel medyczny \\
\hline Przewodnik & $\begin{array}{l}\text { Lekarz prowadzący (także sam } \\
\text { chory dla innych) }\end{array}$ \\
\hline $\begin{array}{l}\text { Nowe doświadczenia, wyzwania, } \\
\text { rozwój, okazja do podziwiania } \\
\text { świata }\end{array}$ & $\begin{array}{l}\text { Przewartościowanie życia } \\
\text { w chorobie, rozwój wewnętrzny, } \\
\text { afirmacja życia tu i teraz }\end{array}$ \\
\hline Wolność w drodze & Decydowanie o sobie w leczeniu \\
\hline Różne tempo, postoje & Prawo do zmęczenia i odpoczynku \\
\hline Koniec drogi & Śmierć \\
\hline
\end{tabular}

Rys. 2. Relacje między elementami ram PODRÓŻY a CHOROBY

$\mathrm{Na}$ podstawie lektury współczesnych tekstów tworzących polski dyskurs medyczny dodałabym do wymienionych wcześniej właściwości metafory PODRÓŻY jeszcze kilka cech. Ujęcie doświadczenia choroby jako PODRÓŻY daje obszerne pole do pokazania różnorodnych analogii między elementami obu domen. Dużą zaletą tej metafory jest to, że nie wiąże się ona z wartościowaniem: 
nie ocenia chorego, który zmarł z powodu choroby. Wprowadza ponadto pozytywne komponenty, takie jak: wolność wyboru, decydowanie o sobie, możliwość rozwoju osobistego, wzrastanie człowieka wraz z rozwojem wydarzeń, szukanie i odnajdywanie sensu życia. Takich właściwości nie ma metafora WALKI.

Domena PODRÓŻY pokazuje również inną rolę lekarza - jako towarzysza chorego, przewodnika, który prowadzi pacjenta przez kolejne etapy doświadczenia choroby. A czasami to pacjent może być przewodnikiem dla lekarza i rodziny. W tym modelu pojęciowym nie ma tak wyraźnej odpowiedzialności lekarza prowadzącego za niepowodzenie leczenia, jaka jest obecna w metaforze militarnej.

Słuszne wydaje się stwierdzenie Reisfielda i Wilsona (2004), że metafora PODRÓŻY, która ma spory potencjał kreatywnych realizacji, może mieć zastosowanie w medycynie XXI wieku, kiedy rak staje się chorobą przewlekłą. Mam poczucie, że jest ona odpowiednia do budowania narracji oraz komunikacji także przy innych chorobach przewlekłych. Specyfiką tych chorób jest to, że wiążą się z długim okresem różnie nasilonej obecności choroby w życiu chorego, który staje się w dziedzinie swojej choroby ekspertem i przewodnikiem dla innych, oraz z długoletnią relacją z lekarzem, która powinna być współpracą, opartą na szacunku i zaufaniu, taką właśnie wspólnie przebytą drogą.

\section{Podsumowanie}

Metafora jest potrzebna wszystkim uczestnikom dyskursu medycznego, choć zapewne każdemu w inny sposób. Pacjent i lekarz mogą dzięki niej tworzyć ramy swojej wspólnej relacji, która będzie obejmowała zarówno narrację (opowiadanie) o chorobie, jak i dostosowane do potrzeb postępowanie medyczne. Rodzinie i bliskim metafora może pomóc zrozumieć, co przeżywa ich chory, i zestawić to z własnym postrzeganiem choroby. Osadzenie opowieści o chorobie w modelu pojęciowym opartym na metaforze pozwala również innym uczestnikom dyskursu, tym niezaangażowanym bezpośrednio (czytelnikom, słuchaczom, obserwatorom - ogólnie społeczeństwu), zrozumieć istotę tego doświadczenia. Metafora w dyskursie medycznym pełni zatem kilka funkcji, z których najważniejsze wydają się: poznawcza i egzegetyczna (Zawisławska 2012) oraz terapeutyczna (Soroko 2006).

Nie ma metafory, która idealnie „wytłumaczy” każdą chorobę, każdą jej fazę i odda w pełni doświadczenie każdego chorego. Każda metafora dostarcza pewnego repertuaru środków, ale nie wyrazi wszystkiego. Poza tym metafory mają swoje „dobre i złe strony”, a tymi złymi są m.in. implikacje metaforyczne, często nieprzewidziane przez nadawcę, które mogą być różne u różnych uczestników dyskursu, nierzadko krzywdzące dla chorych. Wreszcie, nie ma jednej choroby: 
różne choroby, różne fazy chorowania, różni pacjenci wymagają różnych metafor. Tym ważniejsza w komunikacji z chorym staje się wspomniana przez Reisfielda i Wilsona (2004, s. 4027) świadoma elastyczność w doborze języka i ram metaforycznych:

No metaphoric concept is inherently good or bad. Each is contextual. Each has its strengths and weaknesses. Metaphors that are enabling for one patient can complicate the illness experience for another. Metaphorical skill, imagination, and sensitivity are important in creating rapport and in communicating the nature of unshared experience $^{14}$.

\section{Bibliografia}

Domaradzki, J. (2015). Medycyna i jej metafory. O roli metafor w komunikacji lekarz pacjent, Kultura i Edukacja, 3 (109), 27-46.

Doroszewski, J. (2007). Komunikacja pacjenta z lekarzem - literatura, stanowiska, problemy. W: M. Kącka (oprac.), Językowe, psychologiczne i etyczne aspekty komunikacji lekarza z pacjentem (41-62). Warszawa: Rada Języka Polskiego przy Prezydium PAN.

Eichelberger, W., Stanisławska, I. (2013). Być lekarzem, być pacjentem. Rozmowy o psychologii relacji. Warszawa: Wydawnictwo Czarna Owca.

Fillmore, Ch. (1982). Frames Semantics. W: Linguistics in the Morning Calm. Selected Papers from SICOL-1981 (111-137). Seoul: Hanshin Pub. Co.

Fillmore, Ch. (1985). Frames and the semantics of understanding, Querendi di Semantica, 6 (2), 222-255.

Jabłońska, K., Kaczkowski, J. (2017). Żyć aż do końca. Instrukcja obsługi choroby. Warszawa: Wydawnictwo Więź.

Janowicz, A., Krakowiak, P., Małkowska, M. (2017).Współodczuwajmy!, Hospicjum to też zycie, 4 (52), 2-4.

Lakoff, G., Johnson, M. (2010). Metafory w naszym życiu. Tłum. T.P. Krzeszowski. Warszawa: Aletheia.

Libura, A., Libura, M., Bechler, P. (2015). Obraz niezakaźnych chorób przewlekłych w dyskursie potocznym i prasowym na przykładzie chorób reumatycznych i łuszczycy. W: B. Samoliński, F. Raciborski, J. Gołąb (red.), Konstruktywni. Zdrowie, aktywność i zdolność do pracy. Raport (271-318). Warszawa: Wydawnictwo Naukowe SCHOLAR.

${ }_{14}$ Żadna metafora nie jest $\mathrm{z}$ natury dobra ani zła. Wszystko zależy od kontekstu. Każda metafora ma swoje mocne i słabe strony. Metafora, którą przyjmie jeden pacjent, może skomplikować doświadczenie choroby u innego pacjenta. Umiejętności metaforyczne, wyobraźnia i wrażliwość są ważne w budowaniu relacji i w komunikowaniu trudnych do wyrażenia doświadczeń (tłum. - M. Ch.-K.). 
Malinowska, D. (2013). Konceptualizacja choroby w języku angielskim, Prace Językoznawcze, 15/3, 53-63.

Marczewska, M. (2012). Ja cię zamawiam, ja cię wypędzam... CHOROBA. Studium językowo-kulturowe. Kielce: Wydawnictwo Uniwersytetu Jana Kochanowskiego.

Mukherjee, S. (2013). Cesarz wszech chorób. Biografia raka. Tłum. J. Dzierzgowski, A. Pokojska. Wołowiec: Wydawnictwo Czarne.

Niebrzegowska-Bartmińska, S. (2006). Konceptualizacja choroby w polszczyźnie potocznej i w polskich zamówieniach ludowych. W: E. Łoch, G. Wallner (red.), Sposoby leczenia dawniej a dziś w świetle literatury i medycyny, 3 (33-48). Lublin: Wydawnictwo Wojciech Olech.

Reisfield, G.M., Wilson, G.R. (2004). Use of Metaphor in the Discourse on Cancer, Journal of Clinical Oncology, 22 (19), 4024-4027.

Semino, E., Demjén, Z., Hardie, A., Payne, S., Rayson, P. (2018). Metaphor, Cancer and the End of Life: A Corpus-Based Study (Routledge Advances in Corpus Linguistics). New York, London: Routledge.

Sontag, S. (2016). Choroba jako metafora. AIDS i jego metafory. Tłum. J. Anders. Kraków: Wydawnictwo Karakter.

Stec, M. (2007). Konceptualizacja pojęcia choroba w polszczyźnie, Poradnik Językowy, 1, $20-32$.

Soroko, E. (2006). Obecność metafory w relacji terapeutycznej. W: L. Kaczmarek, A. Słysz, E. Soroko (red.), Od systemu terapeutycznego do interwencji. Poznań: Wydawnictwo Uniwersyteckie. Artykuł pozyskano w wersji elektronicznej ze strony: https://www. researchgate.net/publication/256090987_Obecnosc_metafory_w_relacji_terapeutycznej.

Zawisławska, M. (2011). Metafora w języku nauki. Warszawa: Wydawnictwo Wydziału Polonistyki Uniwersytetu Warszawskiego.

Zawisławska, M. (2016). SYNAMET - A Microcorpus of Synesthetic Metaphors. Preliminary Premises of the Description of Metaphor in Discourse, Cognitive Studies|Etudes Cognitives, 16, 107-118.

\section{Streszczenie}

Artykuł dotyczy dwóch metafor pojęciowych obecnych we współczesnym dyskursie medycznym, są to: WALKA Z CHOROBĄ i CHOROBA TO PODRÓŻ. Metodologicznie praca sytuuje się w nurcie lingwistyki kognitywnej, a kontekstem rozważań jest problematyka komunikacji medycznej. Na podstawie literatury przedmiotu i wybranych tekstów należących do polskiego dyskursu medycznego autorka omawia struktury obu metafor opisujących doświadczenie choroby, ich skuteczność oraz możliwe efekty stosowania (treści wnioskowane, implikacje metaforyczne) w zależności od tego, do jakiej choroby i jakiej jej fazy się odnoszą. 